\title{
"Gobak Sodor" in Group Counseling to Improve Interpersonal Communication Skills in Early Childhood
}

\author{
Devi Ratnasari \\ Department of Guidance and Counseling \\ Universitas Indraprasta PGRI \\ Jakarta, Indonesia \\ devi.ratnasari@unindra.ac.id \\ Sabrina Dachmiati \\ Department of Guidance and Counseling \\ Universitas Indraprasta PGRI \\ Jakarta, Indonesia \\ sabrina.dachmiati@unindra.ac.id \\ Wahyu Eka Prasetyaningtyas \\ Department of Guidance and Counseling \\ Universitas Indraprasta PGRI \\ Jakarta, Indonesia \\ wahyueka.prasetyaningtyas@unindra.ac.id
}

\author{
Itsar Bolo Rangka \\ Department of Guidance and Counseling \\ Universitas Indraprasta PGRI \\ Jakarta, Indonesia \\ itsarbolo.rangka@unindra.ac.id \\ Rezky Permata Sari \\ Department of Guidance and Counseling \\ Universitas Indraprasta PGRI \\ Jakarta, Indonesia \\ rezky.permatasari@unindra.ac.id \\ Miskanik \\ Department of Guidance and Counseling \\ Universitas Indraprasta PGRI \\ Jakarta, Indonesia \\ miskanik@unindra.ac.id
}

\begin{abstract}
Interpersonal communication skill is needed to support the glorious success in life. Therefore, the development of interpersonal communication skill can be done as early as possible in early childhood. Refer to American School Counselor Association (ASCA) at the pre-school level of identifying the various interpersonal relationships in their lives and discussing the manners and roles they play in building a comrade, then one of the treatment could be given to improve the interpersonal communication skill is to use the group guidance. "Gobak Sodor" is one of the traditional games in Indonesia. The games core is to block an opponent from passing the line to the last line back and forth. Then, to win all the group members must complete the process back and forth in a predetermined field area. This game has many benefits such as to train concentration and cooperation, and improve interpersonal communication.
\end{abstract}

Keywords-group guidance; gobak Sodor; interpersonal communication; traditional Game.

\section{INTRODUCTION}

Guidance and counseling are an important and integral part of education. One of the principles of guidance and counseling services is to provide services to all circles, whether old or young, male or female, the problematic or not problematic, also includes early childhood with all the unique characteristics they have. The principle is known as "BK for All". BK aims to make individuals understand himself which is then expected to develop their potential optimally. One potential or ability that can be developed in early childhood is the skill to perform interpersonal communication.

Interpersonal communication is the process of sending and receiving messages between two people or among a small group of people, with some effects and some instantaneous feedback[1]. Another similar opinion also reveals that interpersonal communication is a communication consisting of two or more people who are dependent on each other and use a consistent pattern of interaction[2]. Interpersonal communication involves two full personal elements where openness and honesty in communicating is needed, but based on data problems personal closed attitude is often used in communicating interpersonal to maintain the feelings of the opposite of communication, as a result of it can hinder the development of individuals[3].

The establishment of interpersonal communication skills is influenced by several things, including the family and the attitude of the teacher. Based on the results of research[4] conducted on students of class V and VI of 47 students, the results obtained that children who have attachment high to parents are able to communicate more effectively than children who have low attachment, so it can be concluded that there are differences in interpersonal communication skills of children in terms of attachment to parents. In addition, the research conducted[5] of 385 pre-school teachers indicates 
that the attitudes of female teachers who are empathetic and have good social competence can foster interpersonal communication skills in students through the establishment of positive relationships in the classroom.

Development of interpersonal communication skills in early childhood needs to be done so that they have the readiness to face the social environment well around and able to support the glory of life in the future. The negative impact that can arise from lack of interpersonal communication skills is the lack of childhood happiness. There is a strong link between social skills and childhood happiness[6]. The child's ability to adapt to the environment, acceptance of the environment and other positive experiences during social activities is a very important basic capital for a successful and enjoyable life in the future. Another negative impact due to lack of interpersonal communication skills is the inhibition of the achievement of developmental tasks, especially those associated with learning to establish emotional connections with parents, siblings, and others. Development[7] occurs through healthy interaction between individuals and the environment, if the interaction is less healthy then individual development will be disrupted.

Therefore, action is required in order to develop good interpersonal communication skills in early childhood. One of the actions that can be done is to apply group guidance services with the technique of playing "Gobak Sodor". Group guidance is a counseling service given to more than one person at a time[8]. There are several techniques in group guidance, one of which is playing. Solehuddin, et al states that while not oriented towards a particular goal, teachers believe that play has a positive contribution to physical growth and motor behavior and social development, and child activity[9]. A small number of them also believe that playing has a positive value for the development of cognition and readiness to learn children. "Gobak Sodor", selected as a game used in group guidance services, aims to improve students' interpersonal communication skills.

"Gobak sodor" is one of the traditional games that are rarely played by children. This game is very interesting, fun, and very difficult because everyone should always keep watch and run as fast as possible to achieve victory[10]. Therefore, the "Gobak Sodor" game is chosen in group guidance services, because in it there are demands of teamwork and requires communication to victory in the game. Through such communication, participants can develop their interpersonal communication skills better.

\section{METHOD}

This is a literature review. The authors conducted a relevant literature is an essential feature of any academic project[11]. In this case, we collected a literature about "Gobak Sodor", group guidance, early childhood development and other relevant material in this manuscript.

\section{DISCUSSIONS}

\section{A. Understanding Interpersonal Communication}

Interpersonal communication[1] is a social process where people involved in it influence each other. This process of mutual influence is a psychological process and also the beginning of the psychological bond between people who have a personality. Interpersonal communication is also defined as the process of sending and receiving messages between two people or among a small group of people, with some effects and some immediate feedback. In line with that opinion, interpersonal communication is also said to be a faceto-face interaction between two or more people, in which the sender can deliver the message directly and the recipient of the message can receive and respond directly[12].

Interpersonal communication skills include behaviors that involve skills used during social interaction, also called friendship skills, such as introducing themselves, offering help and giving or receiving praise[13]. This skill allows relationships with age and gender. So it can be concluded that interpersonal communication is an interaction that exists between two people or more by exchanging messages or information and the opportunity to do feedback or direct response. Interpersonal communication cannot be separated from human activity as a social creature in accordance with its nature.

\section{B. Factors Affecting the Development of Interpersonal Communication Skills}

There are several factors that play a role in the formation and development of interpersonal communication skills, such as; 1) family, to achieve social maturity, children must learn about ways to adapt to others. This ability is obtained by the child through opportunities or experiences to get along with people in their environment, whether parents, siblings, peers or other adults. The family environment is the first environment that children will recognize[14]. In addition, children who have a high attachment to parents are able to communicate more effectively than children with low attachment[4]. 2) Outdoor environment, which is a place for children to socialize. Outside the house, the child will meet more people, such as peers, smaller people, adults, so social will run according to his role in the neighborhood. 3) School environment, especially about attitude and way of teaching teacher. Based on the research done on the teaching of teachers in early childhood, the results obtained that teachers who use more stories or fairy tales in learning, it can provide opportunities for children to further explore the widespread use of language and stimulate them to communicate the story from another point of view[15]. The behavior of early childhood can further support the development of interpersonal communication skills.

So it can be concluded that family factors such as connection between parents and how parents communicate, environmental factors outside home such as experience of children interact with others, and school environment factors such as attitudes and ways teachers in teaching, it can affect the formation and development of interpersonal communication skills in early childhood. 


\section{The Importance of Interpersonal Communication Skills for Early Childhood}

Early childhood, is in the golden age. At this time the child can learn to prepare himself to be a part of life both as a whole person and as part of social life of society[13]. Therefore, guidance on interpersonal communication skills is important for early childhood, moreover they are the future of the next generation of the nation. The development of interpersonal communication skills from an early age is a good investment in supporting the achievement of child development tasks.

Developmental tasks are tasks that appear at a certain period in the life span of the individual, which if the task can be successfully completed will bring happiness and success in completing the next developmental task[16]. Meanwhile, if it fails, it will cause unhappiness in the individual concerned, cause community rejection, and difficulty in completing the next tasks. Developmental tasks in early childhood related to interpersonal communication skills namely; 1) learn to establish an emotional connection with parents, relatives, and others. 2) learning to establish good and bad relationships, which means developing conscience.

Associated with developmental tasks, there are nine areas of student development according to the American School Counselor Association (ASCA), which serve as the basis for developing the full objectives of comprehensive counseling and guidance programs[17]. The domain associated with interpersonal communication skills in early childhood is the private/social aspect of learning to live. The private/social sphere covers a wide range of activities that can assist students in the development of interpersonal skills with individuals and groups. This aspect is based on the goals of students related to the success of education, career, and life as well as the development of strong positive self-concept. The variety of competencies that can be developed in early childhood related to interpersonal communication skills is about respecting oneself and others covering; 1) identifying and expressing feelings; 2) identifying interpersonal relationships in their lives; 3) identifying vocabulary related to feeling expression; 4) identifying feelings of happiness, sadness, and anger; 5) discussing the manners and roles they play in building friendship.

So it can be concluded that interpersonal communication skills in early childhood is important to be developed in order to support the sequence of achievement of its development tasks, so that they can develop optimally and become a whole person, and become the future of the nation's next generation brilliant.

\section{Understanding Guidance Group Techniques Play "Gobak Sodor"}

Group guidance can be defined as a process of providing assistance to individuals through a group atmosphere that enables each member to learn to participate actively and share experiences in developing the necessary insights, attitudes or skills in an effort to prevent problems or in personal development efforts[17]-[19]. The guidance of the technical group playing "Gobak Sodor" is the process of providing assistance to the individual through group atmosphere by performing a game of "Gobak Sodor" therein, aimed at improving interpersonal communication skills.

"Gobak sodor" is one of the traditional game types in Indonesia. The point of the game is to block an opponent from passing through the line to the last line back and forth, and to win all the members of the group must complete the process back and forth in a predetermined field area. "Gobak sodor" is one of the traditional games that are rarely played by children. This game is very exciting, fun, and very difficult because everyone should always keep watch and run as fast as possible to achieve victory.

Group guidance takes place through four stages[20], which includes; 1) The stage of formation, this stage is the stage of recognition, stage of self-involvement or stage enter into the life of a group. At this stage in general the members introduce each other and also reveal the goals or expectations of each member. 2) The transitional phase, before proceeding further into the actual group activity stage, the group leader explains what the group members will do at a later stage of activities in group activities. The group leader explains the role of group members in the activity, then offers or observes whether the members are ready to go through the activity at a later stage. 3) Stage of activities, this stage is the actual life of the group that is doing the game "Gobak Sodor". However, the continuity of group activities at this stage is highly dependent on the results of the previous two stages. If the previous two stages work well, then the third stage will work smoothly. Group leaders can be more relaxed and allow their own members to do activities without much interference from group leaders. 4) Phase termination. At this stage is the stage of cessation of activities. In this termination there is a group agreement whether the group will continue the activity and meet again and how many times the group meets.

So it can be concluded that the group guidance with "Gobak Sodor" is the process of providing assistance to individuals in a group atmosphere, in which there is a "Gobak Sodor" game activities with the aim to improve the skills of interpersonal communication in early childhood. The guidance of the group is passed in four stages: opening stage, intermediate stage, activity stage, and closing stage.

\section{E. The Influence of Usage Group Guidance Techniques Play "Gobak Sodor" in Improving Interpersonal Communication in Early Childhood}

The essence of the purpose of counseling and guidance lies in independent individuals or in other words independence is the purpose of guidance and counseling[21]. Healthy independence is manifested in the awareness of shared and interdependent states with others. Independence is formed through the interaction of individuals with the environment, and guidance and counseling is responsible for developing enabling development environment. Therefore guidance and counseling efforts are also aimed at building a healthy ecology of human development.

Traditional Indonesian games such as "Gobak Sodor" packaged in group counseling services, can be an effort to guide and counsel in establishing and optimizing early childhood development especially related to interpersonal 
communication skills. There are a number of studies related to the use of games in developing the ability and potential of early childhood. Among them is research conducted about play therapy in school. The research results show that play therapy can be used as an intervention in helping to overcome a number of developmental problems that occur in childhood, such as emotional and academic problems in the school environment[22]. Through the game, children and teenagers can communicate feelings, thoughts, and experiences. However, of course in the implementation, there are several challenges that must be faced. Furthermore, research conducted on the students of class IX junior high as 62 students, obtained the result that model guidance group that use the game (games) effective in improving student interpersonal relationship[2]. Other studies have also been conducted on the use of traditional games in improving social skills in early childhood. The study was conducted on 20 children aged 5-6 years. The results showed that the social skills of grade 2 kindergarten children through traditional game methods could increase by $42.13 \%$ from the preintervention grade average and $54.13 \%$ in posttest results. Some of these studies have proven that games can be used to help develop competence and help address developmental problems in early childhood and adolescence[13].

In the game of "Gobak Sodor", there are stages that require good cooperation and communication in the team to achieve victory. Through such communication, which is packaged in group counseling activities with counselors acting as facilitators, early childhood is expected to develop their interpersonal communication skills better. Moreover, the experience gained through the game of "Gobak Sodor" can teach them about some value that needs to be applied in the game and in conducting interpersonal communication, such as patience, honesty, openness, and awareness.

\section{CONCLUSIONS}

The group guidance of playing "Gobak Sodor" can be an option for counselors in improving interpersonal communication skills in early childhood.

Group guidance activities can be done in four stages namely the stages of formation, intermediate stages, stages of activity, and stages of closure. Interpersonal communication skills in early childhood is important to be developed because it can serve as a stock in the future in reaching the achievement of life and also affect the achievement of its development task sequence as a person with a whole personality and potentially be optimal.

\section{Acknowledgment}

We would like to thank to Dean of Faculty of Education and Social Sciences of Universitas Indraprasta PGRI for the support. We also express our great appreciation to Ms. Nosmalasari for technical help in this manuscript.

\section{References}

[1] J. A. DeVito, The Interpersonal Communication Book, vol. 32. 2008.

[2] M. N. Loban, M. E. Wibowo, and E. Purwanto, "Jurnal Bimbingan
Konseling Model Bimbingan Kelompok menggunakan Games untuk Meningkatkan Hubungan Interpersonal Siswa Abstrak," vol. 6, no. 1, pp. 54-61, 2017.

[3] E. Trisnaningtyas and M. Nursalim, "Penerapan Latihan Asertif Untuk Meningkatkan Keterampilan komunikasi interpersonal siswa," ... Thesis, Univ. Negeri ..., 2009.

[4] A. P. Widawati and M. S. \& Budiani, "Perbedaan Kemampuan Komunikasi Interpersonal Anak Ditinjau Dari Attachment Terhadap Orangtu," E-Journal UNESA, vol. 1, p. 2, 2013.

[5] E. Ahmetoglu and I. H. Acar, "The Correlates of Turkish Preschool Preservice Teachers' Social Competence, Empathy and Communication Skills," Eur. J. Contemp. Educ., vol. 16, no. 2, pp. 188-197, 2016.

[6] F. Mayar, "Perkembangan Sosial Anak Usia Dini Sebagai Bibit Untuk Masa Depan Bangsa," AL-Ta lim, vol. 20, no. 3, p. 459, 2013.

[7] S. Kartadinata, "Teori Bimbingan dan Konseling," Seri Landasan Teori Bimbingan dan Konseling. pp. 1-14, 2007.

[8] W. Sri Hastuti and W. S. Winkel, "Bimbingan dan Konseling di Institusi Pendidikan.” Yogyakarta: Media Abadi, 2004.

[9] S. Kadek, "Efektivitas Penggunaan Teknik Permainan dalam Bimbingan Kelompok untuk Meningkatkan Kepercayaan Diri Siswa,"Ed. Khusus, no. 1, pp. 127-138, 2011.

[10] V. Iswantiningtyas and I. P. Wijaya, "Meningkatkan Kemampuan Motorik Kasar Anak Usia Dini Melalui Permainan Tradisional Gobak Sodor," Pinus, vol. 1, no. 3, pp. 249-251, 2015.

[11] J. Webster and R. Watson, "Analyzing the past to prepare for the future: Writing a literature review," MIS Q., vol. 26, no. 2, 2002.

[12] Hardjana, "Komunikasi intrapersonal dan interpersonal." Kanisius, Jakarta, 2003.

[13] I. \& A. S. Desi, Rahayu \& Solihin, "Peningkatan Keterampilan Sosial Anak Usia Dini Melalui Permainan Tradisional," Antol. UPI, pp. 1-9, 2016.

[14] H. Elizabeth, Perkembangan anak jilid I. Jakarta: Erlangga, 1995.

[15] E. E. Flynn, "Language-Rich Early Childhood Classroom: Simple but Powerful Beginnings," Read. Teach., vol. 70, no. 2, pp. 159-166, 2016.

[16] S. Yusuf, Psikologi perkembangan anak dan remaja. Bandung: Remaja Rosdakarya, 2011.

[17] N. Rusmana, Bimbingan dan Konseling Kelompok di Sekolah. Bandung: Rizky Press, 2009.

[18] I. B. Rangka, "Implementasi Pembelajaran Karakter-Cerdas Melalui Kegiatan Kelompok," in Seminar Nasional Pendidikan PGRI 2017, 2017, pp. 491-498.

[19] S. Folastri and I. B. Rangka, Prosedur Layanan Bimbingan dan Konseling Kelompok. Bandung: Mujahid Press, 2015.

[20] Prayitno, Seri Layanan Konseling (Layanan Bimbingan Kelompok dan Konseling Kelompok). Padang: Universitas Negeri Padang, 2004.

[21] I. B. Rangka, "Konseling Indigenous: Rekonstruksi Konseling di Tengah Keragaman Budaya," in Optimalisasi Peran Konselor melalui Pemanfaatan Berbagai Pendekatan dan Terapi dalam Pelayanan Konseling, 2016, pp. 19-20.

[22] B. Lauren and S. Wynne, "Play Therapy in School Settings," International Journal. pp. 2005-2007, 2008. 